Volume 10 Issue 3, July-September 2016: pp. 413-586. Copyright (c) 2015-2016 FIAT JUSTISIA. Faculty of Law, Lampung University, Bandarlampung, Lampung, Indonesia. ISSN: 1978-5186 | e-ISSN: 2477-6238.

Open Access: http://jurnal.fh.unila.ac.id/index.php/fiat

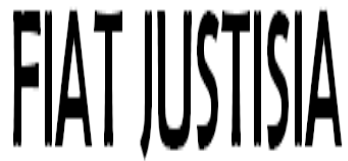

Fiat Justisia is licensed under a Creative Commons Attribution 4.0 International License, which permits unrestricted use, distribution, and reproduction in any medium, provided the original work is properly cited.

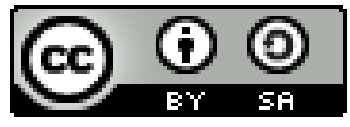

\title{
PERAN BADAN PERMUSYAWARATAN DESA DALAM MEWUJUDKAN PEMBENTUKAN PERATURAN DESA YANG PARTISIPATIF DI KABUPATEN LAMPUNG TIMUR
}

\section{The Role of the Village Representative Board in Realizing the Establishment of Village Regulation who Participative in East Lampung District}

\author{
Ahadi Fajrin Prasetya \\ Universitas Tulang Bawang, Bandarlampung \\ email: fajrihadi@rocketmail.com
}

\begin{abstract}
The objective of this research was to find out why the Village Representative Board (BPD) was not yet able to draft participative village regulations in East Lampung district. This was a qualitative research with normative and empirical jurisdiction approaches with literary study, statute approach, case approach and historical approach. Data were collected with the literary study. The results showed that the role of Village Representative Board (BPD) and drafting village regulation has been exercised in a participative way but not optimal because of some factors. The village regulation should be drafted by $B P D$, but the village regulation was initiated and drafted by Head of Village. BPD lack of knowledge related to their tasks and functions in village legislation, mechanism and process of making participative village regulation, and BPD was less optimal in making synergy with public related to participative village regulation making. The rights of the public in Bojong village has been participative in making village regulation but not optimal as it was regulated Article 96 of Law Number 12 of 2011 on legislation related to public participation rights. The making of village regulation in Bojong so far was conducted with village public deliberation by public figures as public representatives of each sub-villages to deliver public aspiration in making village regulation in Bojong village. Interview results with the chairman of BPD in Bojong village suggested that village deliberation in making village regulation was only a formality because the
\end{abstract}


majority of participants such as public figures, religion figures, youth figures, and members of BPD almost always agreed with any draft of village regulation proposed by village government.

Keywords: Village Representative Board (BPD), village regulation, participative

\begin{abstract}
Abstrak
Tujuan dari penelitian ini adalah untuk mengetahui mengapa Badan Permusyawaratan Desa (BPD) belum mampu menyusun peraturan desa yang partisipatif di Kabupaten Lampung Timur. Ini merupakan penelitian kualitatif dengan yuridis normatif dan empiris pendekatan dengan studi sastra, pendekatan undang-undang, pendekatan kasus dan pendekatan historis. Data dikumpulkan dengan studi sastra. Hasil penelitian menunjukkan bahwa peran Badan Permusyawaratan Desa (BPD) dan penyusunan peraturan desa telah dilakukan dengan cara partisipatif tetapi tidak optimal karena beberapa faktor. Peraturan desa harus disusun oleh $\mathrm{BPD}$, tapi peraturan desa yang digagas dan dirancang oleh Kepala Desa. BPD kurangnya pengetahuan yang berkaitan dengan tugas dan fungsi mereka dalam undang-undang desa, mekanisme dan proses pembuatan peraturan desa partisipatif, dan BPD kurang optimal dalam membuat sinergi dengan masyarakat terkait partisipatif pembuatan peraturan desa. Hak-hak masyarakat di Desa Bojong telah partisipatif dalam membuat peraturan desa tetapi tidak optimal seperti yang diatur Pasal 96 UU Nomor 12 Tahun 2011 tentang undang-undang yang berkaitan dengan hak-hak partisipasi publik. Pembuatan peraturan desa di Bojong sejauh dilakukan dengan desa musyawarah publik oleh tokoh-tokoh masyarakat sebagai perwakilan masyarakat dari masing-masing sub desa untuk menyampaikan aspirasi masyarakat dalam membuat peraturan desa di Desa Bojong. Hasil wawancara dengan ketua BPD di Desa Bojong menyarankan bahwa musyawarah desa dalam membuat peraturan desa hanya formalitas, karena mayoritas peserta seperti tokoh masyarakat, tokoh agama, tokoh pemuda, dan anggota BPD hampir selalu setuju dengan rancangan peraturan desa diusulkan oleh pemerintah desa.
\end{abstract}

Kata Kunci: Badan Permusyawaratan Desa (BPD), Peraturan Desa, Partisipatif

\title{
A. Pendahuluan
}

Dalam rangka mencapai tujuan Negara Kesatuan Republik Indonesia (NKRI), sebagai negara berkembang, Indonesia selalu berusaha untuk mencapai kemajuan di segala bidang sebagaimana yang tertuang di dalam 
Penjelasan Undang-Undang Dasar 1945 yaitu "melindungi segenap tumpah darah Indonesia, memajukan kesejahteraan umum, mencerdaskan kehidupan bangsa serta ikut melaksanakan ketertiban dunia berdasarkan keadilan sosial".

Untuk itu pemerintah Indonesia telah melaksanakan pembangunan di segala bidang diseluruh wilayah Indonesia baik dipusat, didaerah dan sampai ke desa-desa. Pembangunan pedesaan, merupakan bagian yang integral dari pembangunan nasional dan pembangunan nasional tidak dapat dipisahkan, karena tolak ukur keberhasilan pembangunan nasional sangat ditentukan oleh keberhasilan pembangunan yang dilaksanakan di desa-desa.

Hal ini dapat terjadi disebabkan bahwa desa merupakan bagian unit terkecil dari wilayah pembangunan. Menurut Pasal 1 huruf b Undangundang Nomor 5 Tahun 1979, disebutkan bahwa desa adalah suatu wilayah yang ditempati oleh sejumlah penduduk sebagai kesatuan masyarakat hukum yang mempunyai organisasi pemerintah yang terendah langsung dibawah camat dan berhak menyelenggarakan urusan rumah tangganya sendiri dalam NKRI.

Undang-Undang Nomor 6 Tahun 2014 Tentang Desa memberikan pengertian desa adalah desa dan desa adat atau yang disebut dengan nama lain, selanjutnya disebut desa, merupakan kesatuan masyarakat hukum yang memiliki batas wilayah yang berwenang untuk mengatur dan mengurus urusan pemerintahan, kepentingan masyarakat setempat berdasarkan prakarsa masyarakat, hak asal usul, dan hak tradisional yang diakui dan dihormati dalam sistem NKRI.

Dari pengertian tersebut, maka desa mempunyai kedudukan strategis sebagai ujung tombak serta sebagai tolak ukur dalam melaksanakan dan mengevaluasi pembangunan nasional secara integral. Dalam menyelenggarakan pemerintahan desa terdapat perangkat desa yang salah satunya yaitu Badan Permusyawaratan Desa (BPD) sebagai lembaga yang melaksanakan fungsi pemerintahan secara demokratis.

Undang-Undang 32 Tahun 2004 tentang Pemerintahan Daerah mengganti sistem perwakilan dalam bentuk BPD. Pasal 210 Undang-Undang 32 Tahun 2004 menegaskan bahwa: "Anggota BPD adalah wakil dari penduduk desa bersangkutan yang ditetapkan dengan cara musyawarah mufakat".

Di desa sering muncul aturan dalam musyawarah untuk menentukan siapa yang menjadi pemimpin masyarakat yang dilibatkan dalam BPD. Aturannya adalah penunjukan secara terpilih terhadap orang yang menjadi pemimpin masyarakat yang dianggap dekat dengan Kepala Desa (Kades).

Akibatnya adalah ketiadaan akses rakyat biasa untuk berpartisipasi sebagai anggota BPD. Fungsi BPD juga dihilangkan, yaitu hanya 
menetapkan Peraturan Desa (Perdes) bersama Kades, menampung, dan menyalurkan aspirasi masyarakat.

Hal tersebut bertentangan dengan apa yang dijelaskan dalam UndangUndang (UU) Nomor 6 tahun 2014 tentang Desa bahwa BPD atau yang disebut dengan nama lain adalah lembaga yang melaksanakan fungsi pemerintahan yang anggotanya merupakan wakil dari penduduk desa berdasarkan keterwakilan wilayah dan ditetapkan secara demokratis.

Dari penjelasan tersebut dapat menimbulkan persoalan bahwa BPD sebagai lembaga yang menjalankan fungsi pemerintahan tidak dapat menjalankan perannya sebagai lembaga perwakilan dalam mewujudkan pembentukan perdes yang demokratis. Hal ini didasarkan bahwa untuk menentukan siapa pemimpin masyarakat yang dilibatkan dalam BPD mekanisme penunjukan hanya sebatas sejauh mana calon pemimpin tersebut dekat dengan Kades.

Selanjutnya, didalam susunan Hierarki ${ }^{1}$ Peraturan PerundangUndangan, Perdes ${ }^{2}$ tidak termasuk didalam urutan Hierarki tersebut. Sebaliknya, Perdes berada diluar Hierarki Peraturan Perundang-Undangan yang terdapat pada Pasal 8 UU Nomor 12 Tahun 2011 tentang Pembentukan Peraturan Perundang-Undangan ${ }^{3}$. Walaupun Perdes berada diluar Hierarki Peraturan Perundang-Undangan, namun keberadaaan Perdes tersebut mempunyai kekuatan hukum tetap dan diakui keberadaannya dalam Peraturan Perundang-Undangan. Sistem pembuatannya setingkat dibawah peraturan Bupati/Walikota.

Dalam penyelenggaraan pemerintah desa $^{4} \mathrm{BPD}$ mempunyai peran dalam mengawasi dan meminta keterangan tentang penyelenggaraan pemerintahan desa kepada pemerintah desa. Lemahnya partisipasi masyarakat dan pendidikan masyarakat di desa merupakan sisi lain dari lemahnya praktik demokrasi ditingkat desa. Sampai sekarang, elite desa tidak mempunyai pemahaman mengenai Perdes, dan pemerintahan desa ${ }^{5}$.

\footnotetext{
${ }^{1}$ Pasal 7 Undang-Undang Nomor 12 Tahun 2011 tentang Pembentukan Peraturan PerundangUndangan Jenis dan Hierarki Peraturan Perundang-Undangan terdiri atas: a.UndangUndang Dasar 1945;b. Ketetapan Majelis Permusyawaratan Rakyat; c. Undang-Undang/ Peraturan Pemerintah Pengganti Undang-undang;d. Peraturan Pemerintah; e. Peraturan Presiden; f. Peraturan Daerah Provinsi; dan g. Peraturan Daerah Kabupaten/Kota.

2 Menurut Undang-Undang Nomor 6 Tahun 2014 tentang Desa yang dimaksud dengan peraturan desa adalah peraturan perundang-undangan yang ditetapkan oleh Kepala Desa setelah dibahas dan disepakati bersama Badan Permusyawaratan Desa.

${ }^{3}$ Sasongko, Wahyu. (2013). Sejarah Tata Hukum Indonesia, Bandar Lampung: PKKPU FH Unila, p. 100.

${ }^{4}$ Pemerintah desa adalah kepala desa atau yang disebut dengan nama lain dibantu perangkat desa sebagai unsur penyelenggara pemerintahan desa.

5 Pemerintahan desa adalah penyelenggaraan urusan pemerintahan dan kepentingan masyarakat setempat dalam sistem pemerintahan Negara Kesatuan Republik Indonesia.
} 
Semua hal yang terkait dengan Perdes, Pembangunan desa ${ }^{6}$, Pengelolaan Keuangan Desa ${ }^{7}$ dan Pemerintahan Desa selesai hanya di kades saja. Untuk mewujudkan tujuan penataan desa $^{8}$ sebagaimana yang dimaksud pada Pasal 7 ayat (3) dibutuhkan Perdes sebagai pedoman dan aturan hukum yang mengikat.

Dari hal tersebut menunjukan bahwa betapa pentingnya Perdes dalam menyelenggarakan pemerintahan desa. Tetapi permasalahan yang timbul adalah Kades dengan menggunakan kewenangannya sebagai Kades, merancang Perdes yang seharusnya dikerjakan bersama dengan $\mathrm{BPD}^{9}$ ia kerjakan sendiri dan perencanaan pembangunan dia kerjakan berdua sekretaris desa dengan sistem bagi hasil berdua.

UU Nomor 6 Tahun 2014 tentang Desa menjelaskan bahwa yang dimaksud dengan perangkat desa terdiri dari sekretaris desa, pelaksanaan kewilayahan, dan pelaksana teknis. Selain itu, ada BPD yang mempunyai fungsi membahas dan menyepakati rancangan Perdes bersama Kades.

Dari hal tersebut, dapat disimpulkan bahwa BPD selaku lembaga yang menjalankan fungsi pemerintahan di desa yang seharusnya bekerjasama dengan perangkat desa dalam pembentukan Perdes secara partisipatif dengan menampung hal-hal yang menjadi aspirasi masyarakat desa dan kebutuhan masyarakat desa. Akan tetapi, BPD tidak dapat menjalankan peran dan fungsinya sebagaimana yang ditetapkan dalam UU dikarenakan tidak dilibatkan dalam urusan pemerintahan desa.

Metode penelitian dilakukan dalam usaha untuk memperoleh data yang akurat serta dipertanggungjawabkan kebenarannya. Penelitian hukum, merupakan hal yang ilmiah yang didasarkan pada metode, sistematis, dan pemikiran tertentu dengan jalan menganalisisnya. Selain itu juga, diadakan pemeriksaan yang mendalam terhadap fakta hukum tersebut untuk kemudian mengusahakan suatu pemecahan atas permasalahan yang timbul. ${ }^{10}$

\footnotetext{
${ }^{6}$ Pembangunan desa adalah upaya peningkatan kualitas hidup dan kehidupan untuk sebesarbesarnya kesejahteraan masyarakat desa.

${ }^{7}$ Keuangan desa adalah semua hak dan kewajiban desa yang dapat dinilai dengan uang serta segala sesuatu berupa uang dan barang yang berhubungan dengan pelaksanaan hak dan kewajiban desa.

8 Penataan sebagaimana yang dimaksud bertujuan untuk: a. Mewujudkan efektivitas penyelenggaraan pemerintahan desa; b. Mempercepat peningkatan kesejahteraan masyarakat desa;c. Mempercepat peningkatan kualitas pelayanan publik; d. Meningkatkan kualitas tata kelola pemerintahan desa;dan; e. Meningkatkan daya saing desa.

${ }^{9}$ Badan Permusyawaratan Desa adalah lembaga yang melaksanakan fungsi pemerintahan yang anggotanya merupakan wakil dari penduduk desa berdasarkan keterwakilan wilayah dan ditetapkan secara demokratis.

${ }^{10}$ Muhammad, Abdulkadir. (2004). Hukum dan Penelitian Hukum. Bandung: PT Citra Aditnya Bhakti, p. 43.
} 


\section{B. Pembahasan}

\section{Gambaran Umum Lokasi Penelitian di Desa Bojong Lampung Timur}

\section{a. Sejarah Desa}

Desa Bojong dahulu adalah salah satu yang masuk ke dalam Mergo Sekampung Limo Migo, dari abad ke- 13 telah dihuni oleh orang-orang asli pribumi/ suku lampung, sebagai bukti adanya penghuni pada saat itu, adanya makam kerajaan/Keratuan Pugung yang terletak di desa Pugung Raharjo. Desa Pugung Raharjo merupakan hibah dari desa Bojong pada Tahun 1940.

Pada masa kerajaan desa Bojong pada saat itu penduduknya pada awal-awal kerajaan Banten berkembang, beberapa orang penduduk berguru dan belajar agama Islam. Dikuatkan dengan adanya makam yang dikeramatkan yang telah memeluk agama Islam dan keramat itu berada di desa Bojong, diantara keramat canggung yang dipimpin oleh Minak Keramat, Wali Unang di Way Sekampung yang masih keturunan warga Bojong.

Keramat kecubung berada di desa Bojong yang dipimpin oleh seorang wali Guling Manik, Keramat Ngetiko Tuan yang terletak dimakam umum tujuh Bojong, menjadi asal perkampungan tujuh Bojong yaitu dari tiap-tiap umbul/kelompok yang menetap dibawah naungan keramat.

Kata Bojong itu sendiri yang berarti tanah menjorok dari dua sengai/way yaitu way bujung dan way tujuh yang mana posisi tiyuh bujung yang sebenarnya yaitu makam umum tujuh bojong sekarang; dan nama Bojong yang sebenarnya adalah Bujung Katon Negeri Sakti yang bermakna: bujung bermakna tanah yang menjorok, Katon bermakna kelihatan/ Tampak negeri bermakna wilayah, sakti maksudnya tidak pernah dijajah atau dikuasai orang lain.

Bujung termasuk suatu wilayah hukum dibawah naungan/ kepemimpinan Pesirah mergo sekampung, pesirah mergo sekampung adalah suatu pimpinan yang mengatur suatu adat istiadat dan mengelola pemerintahan. Mergo sekampung memiliki wilayah yaitu, Bujung, Toba, Gunung Sugih, Gunung Raya, dan Batu Badak. Yang pertama kali menjabat sebagai kepalo tujuh bujung pada saat itu adalah Ibrahim Gelar Betaro Rajo.

Bersama dengan perkembangan jaman sebutan tujuh bujung, dirubah menjadi Bojong yang telah disepakati dalam Merwatin (acara adat) untuk selanjutnya, pertama kali melakukan pemilihan Kades pada tahun 1901 yang diikuti oleh 2 orang dan menjadi Kades adalah Hi. Ibrahim Gelar Betaro Rajo. 


\section{b. Kondisi Umum Desa \\ 1) Geografis}

Desa Bojong merupakan salah satu dari 15 desa di wilayah Kecamatan Sekampung Udik, yang terletak 500 (lima ratus) meter ke arah utara dari kecamatan. Desa bojong mempunyai luas wilayah $1715 \mathrm{Ha}$.

Iklim Desa Bojong sebagaimana desa-desa lain di wilayah Indonesia mempunyai iklim kemarau dan penghujan, hal tersebut mempunyai pengaruh langsung terhadap pola tanam yang ada di desa Bojong Kecamatan Sekampung Udik Lampung Timur.

\section{2) Keadaan Sosial Ekonomi Penduduk}

Desa Bojong mempunyai jumlah penduduk 3980 jiwa, yang tersebar dalam 6 dusun dengan perincian sebagaimana tabel:

\begin{tabular}{|c|c|c|c|c|c|c|}
\hline $\begin{array}{c}\text { Dusun } \\
\text { I }\end{array}$ & $\begin{array}{c}\text { Dusun } \\
\text { II }\end{array}$ & $\begin{array}{c}\text { Dusun } \\
\text { III }\end{array}$ & $\begin{array}{c}\text { Dusun } \\
\text { IV }\end{array}$ & $\begin{array}{c}\text { Dusun } \\
\text { V }\end{array}$ & $\begin{array}{c}\text { Dusun } \\
\text { VI }\end{array}$ & $\begin{array}{c}\text { Dusun } \\
\text { VII }\end{array}$ \\
\hline 323 & 527 & 342 & 735 & 844 & 505 & 839 \\
\hline
\end{tabular}

\section{3) Tingkat Pendidikan}

Tingkat pendidikan masyarakat desa Bojong adalah sebagai berikut:

\begin{tabular}{|l|l|l|l|l|}
\hline Pra sekolah & SD & SMP & SLTA & Sarjana \\
\hline 1683 & 1262 & 665 & 450 & 55 \\
\hline
\end{tabular}

Dari keterangan tabel diatas terkait dengan tingkat pendidikan di desa Bojong, dapat terlihat bahwa begitu rendahnya tingkat pendidikan masyarakat di desa Bojong yang mana dapat terlihat di tabel didominasi oleh banyak masyarakat yang tingkat pendidikan nya tidak sekolah, dan minimnya lulusan sarjana di desa Bojong tersebut.

\section{Proses Pembentukan Perdes Yang Partisipatif Dalam Pelaksanaanya Di Desa Bojong}

Di dalam proses pembentukan Perdes yang partisipatif, dalam pelaksanaanya di desa Bojong, dari hasil penelitian yang dilakukan penulis terkait proses pembentukan Perdes, di desa Bojong melalui wawancara dengan pihak Eksekutif, Legislatif, dan Masyarakat desa Bojong, penulis akan menjabarkannya sebagai berikut: 


\section{a. Hasil Wawancara Penulis dengan Pihak Eksekutif Desa Bojong}

Bapak Hasan Waka selaku Kades Bojong ${ }^{11}$ periode 1999-2013, pada tanggal 21 Maret 2015 mengatakan bahwa proses pembentukan Perdes di desa Bojong yaitu sebagai berikut:

1) Dilakukan musyawarah desa yang diprakarsai oleh BPD, dengan mengundang seluruh Pamong desa, tokoh masyarakat, tokoh agama, tokoh adat, tokoh pemuda, Kades, Sekdes, BPD,dan LPMD;

2) Meminta masukan dari seluruh undangan yang datang terkait dengan rancangan Perdes tersebut;

3) Setelah memperoleh masukan tersebut, rancangan Perdes ditetapkan oleh Kades setelah dibahas dan disepakati oleh BPD.

4) Rancangan Perdes sebagaimana dimaksud ditetapkan oleh Kades dengan membubuhkan tanda tangan terhitung sejak diterimanya rancangan Perdes dari pimpinan BPD.

Hal yang menarik dalam hasil wawancara penulis dengaan Bapak Hasan Waka, beliau berpendapat bahwa penetapan rancangan Perdes menjadi Perdes dapat ditetapkan dalam waktu 1 (satu) hari terhitung sejak tanggal kesepakatan. Alasan bapak Hasan Waka, terkait penetapan tersebut dikarenakan sudah terjadi kesepakatan, kenapa harus diperlambat dengan mengikuti prosedur, hal tersebut beralasan menurut Bapak Hasan Waka selaku Kades dikarenakan sudah terjadi kesepakatan antara BPD dan Kades, dan sudah melalui tahapan dan prosedur yang benar dengan melakukan musyawarah desa.

Dasar hukum yang digunakan dalam pembentukan Perdes, menurut Kades Bapak Hasan Waka menggunakan UU Nomor 32 Tahun 2004 tentang Pemerintah Daerah. Selanjutnya, dari hasil wawancara penulis dengan Bapak Hasan Waka, dan dari beberapa sumber hasil wawancara dengan beberapa masyarakat desa Bojong (Bapak Ismail, Bapak Ami, dan Bapak Yusuf) bahwa Bapak Hasan Waka adalah Kades yang masa jabatan menjadi Kades paling lama. Hal tersebut dikarenakan bahwa Bapak Hasan Waka dipercayai oleh masyarakat desa Bojong mampu menjalankan penyelenggaraan pemerintahan di desa Bojong.

Hal yang lain, menjadi alasan masyarakat desa Bojong menurut Bapak Ismail, Bapak Ami, dan Bapak Yusuf dikarenakan Bapak Hasan Waka selama ini dianggap sebagai pemimpin yang mampu melindungi dan menyelesaikan permasalahan yang dialami warga masyarakat desa Bojong. Permasalahan yang dimaksud, salah satunya terkait dengan permasalahan hukum yang terjadi dengan salah satu masyarakat desa yang terlibat permasalahan dengan aparat hukum.

${ }^{11}$ Menurut Bapak Hasan Waka saat diwawancarai pada hari Sabtu 21 Maret 2015, Pukul 15.00 WIB. 
Dalam hal ini aparat hukum tidak bisa bertindak masuk untuk menangkap salah satu masyarakat desa Bojong yang terlibat dengan masalah hukum. Untuk bisa masuk dan menangkap salah satu warga masyarakat yang terlibat dengan masalah hukum aparat hukum harus meminta izin dengan Bapak Hasan Waka untuk boleh atau tidaknya aparat hukum untuk masuk dan menangkap masyarakat desa Bojong.

Menurut Bapak Ismail, Bapak Ami, dan Bapak Yusuf hal tersebut terjadi dikarenakan, peran Bapak Hasan Waka sebagai Kades Bojong yang sangat mempunyai pengaruh besar di desa Bojong dan mempunyai andil besar dalam proses pembangunan Polsek Lampung Timur. Hal yang paling penting yang alasan Bapak Hasan Waka menjadi Kades dengan masa jabatan terlama dikarenakan Bapak Hasanudin Waka adalah keturunan Kades Bojong pertama kali (hasil wawancara dari Bapak Ismail, Bapak Ami, dan Bapak Yusuf).

Berdasarkan hasil penjelasan diatas, terkait wawancara dengan Bapak Hasan Waka selaku Kades dan Bapak Ismail, Bapak Ami, dan Bapak Yusuf, penulis menyimpulkan bahwa Bapak Hasan Waka merupakan Kades Bojong yang memegang jabatan menjadi Kades paling lama. Hal tersebut dikarenakan, Bapak Hasan Waka dipercayai oleh masyarakat desa Bojong mampu menajalankan penyelenggaraan pemerintahan desa Bojong. Berdasarkan hasil wawancara dengan Bapak AMI, Bapak Ismail dan Bapak Yusuf selaku masyarakat desa Bojong, diperoleh keterangan bahwa Bapak Hasan Waka merupakan keturunan Hi. Ibrahim Gelar Betaro Rajo yang merupakan Kades pertama di desa Bojong.

Selanjutnya, menurut Bapak Ali Imron selaku Sekretaris Desa ${ }^{12}$ (Sekdes) periode 1999-2013 berpendapat tidak jauh beda dengan yang dijelaskan oleh Bapak Hasan Waka, bahwa dalam proses penyusunan Perdes dilakukan dengan tahapan sebagai berikut :

1) Dilakukan musyawarah desa yang diprakarsai oleh BPD, dengan mengundang seluruh Pamong desa, tokoh masyarakat, tokoh agama, tokoh adat, tokoh pemuda, Kades, Sekdes, BPD,dan LPMD;

2) Meminta masukan dari seluruh undangan yang datang terkait dengan rancangan Perdes tersebut;

3) Setelah memperoleh masukan tersebut, rancangan Perdes ditetapkan oleh Kades setelah dibahas dan disepakati oleh BPD.

4) Rancangan Perdes sebagaimana dimaksud ditetapkan oleh Kades dengan membubuhkan tanda tangan terhitung sejak diterimanya rancangan Perdes dari pimpinan BPD.

12 Menurut Bapak Ali Imron selaku Sekdes saat diwawancarai, pada hari Sabtu 21 Maret 2015, Pukul 17.00 WIB. 
Selanjutnya hal yang menarik menjadi perhatian penulis pada saat wawancara dengan Bapak Ali Imron selaku Sekdes beliau tidak mempunyai arsip terkait Perdes yang telah dibuat selama masa jabatan beliau menjadi Sekdes. Bapak Ali Imron beralasan dikarenakan beliau tidak menjabat lagi menjadi Sekdes dan terkait dengan arsip-arsip Perdes masa periode jabatan beliau sudah hilang dan tidak mengetahui berkas-berkasnya disimpan dimana dikarenakan bukan tanggung jawab Bapak Ali Imron.

Selanjutnya, menurut Bapak Kausar, S.E. selaku Kades Bojong ${ }^{13}$ periode 2013-2018 terkait dengan pembentukan Perdes yang demokratis di desa Bojong, beliau berpendapat bahwa terkait tahapan proses pembentukan Perdes sebagai berikut :

1) Kades mengusulkan rancangan Perdes kepada ketua BPD, selanjutnya ketua BPD sebagai lembaga pembentukan Perdes melanjutkan dan menyampaikan rancangan tersebut dalam musyawarah desa yang dihadiri oleh para tokoh-tokoh masyarakat, tokoh agama, tokoh adat, Kades, Sekdes, dan BPD dibalai desa.

2) Dalam musyawarah desa yang diadakan BPD, diharapkan masukan dari anggota yang hadir di balai desa untuk dimintai masukan terkait dengan draft tersebut.

3) Setelah diperoleh masukan dari anggota yang hadir dalam musyawarah, rancangan Perdes disampaikan oleh pimpinan BPD kepada Kades untuk ditetapkan untuk menjadi Perdes paling lambat 7 (tujuh hari) terhitung sejak tanggal yang ditetapkan.

Dalam hal pembentukan Perdes di desa Bojong, Bapak Kausar selaku Kades Bojong tidak dapat berpendapat banyak terkait Perdes yang ada di desa Bojong. Dikarenakan bahwa, Bapak Kausar baru mulai menjabat menjadi Kades pada tahun 2013 sampai sekarang di desa Bojong. Dari hasil wawancara penulis dengan Bapak Kausar beliau beralasan bahwa hal-hal yang terkait dengan Perdes yang ada di desa Bojong beliau tidak memiliki arsip-arsip Perdes yang berlaku di desa Bojong selama ini.

Hal itu terjadi dikarenakan pada saat penyerah terimaan jabatan dari Kades periode sebelumnya kepada Bapak Kausar tidak memperoleh keterangan apapun dari Kades yang lama tentang bagaimana hal-hal terkait dengan arsip-arsip Perdes yang berlaku di desa Bojong, sumber-sumber pendapatan desa Bojong, dan hal-hal yang terkait dengan administrasi pemerintah desa Bojong. Hal tersebut yang menjadi alasan Bapak Kausar sehingga beliau selaku Kades di desa Bojong tidak bisa banyak berpendapat terkait masalah Perdes.

${ }^{13}$ Menurut Bapak Kausar selaku Kades saat diwawancarai pada Hari Sabtu 21 Maret 2015, Pukul 19.00 WIB. 
Terkait hasil pembentukan Perdes yang sampai sekarang ini selama beliau menjabat baru ada satu Perdes yaitu Perdes tentang APBDes tahun 2014. Dari hasil wawancara tersebut bapak Kausar berpendapat bahwa beliau saat ini belum terfokus mengutamakan pembentukan Perdes, dikarenakan Bapak Kausar untuk saat ini lebih ingin mengutamakan Program Kerja untuk ditahun ini untuk membenahi beberapa hal terkait dengan sistem administrasi pemerintah desa, arsip-arsip desa, dan dalam waktu dekat akan diadakan lokakarya desa.

\section{b. Hasil Wawancara dengan Pihak Legislatif Desa Bojong}

Ketua BPD desa bojong Bapak Bachtiar ${ }^{14}$ periode 2009-2013 mengatakan bahwa tahapan dalam proses pembuatan Perdes yaitu:

1) Para peserta undangan hadir dibalai desa yang terdiri oleh seluruh pamong, tokoh masyarakat, tokoh adat, tokoh agama, pemuda, Kades, Sekdes, BPD, dan LPMD. Minimal 50\% anggota yang yang hadir dalam musyawarah desa.

2) Para peserta yang hadir, mengisi formulir daftar hadir yang telah disediakan oleh panitia. Hal tersebut bertujuan untuk melihat seberapa besar partisipasi peserta yang hadir dalam musyawarah desa dan akan dijadikan sebagai berita acara.

3) Dilakukan musyawarah terkait dengan rancangan Perdes yang diprakarsai oleh Pemerintah desa.

4) Rancangan Perdes tersebut disusun oleh Kades. Menurut penulis, hal ini menunjukan bahwa pihak Kades lebih dominan menyusun rancangan Perdes.

5) Setelah dilakukan musyawarah, dan diperoleh hasil dari musyawarah tahap selanjutnya rancangan Perdes tersebut, ditetapkan oleh Kades untuk ditetapkan menjadi Perdes paling lambat 7 (tujuh) hari terhitung sejak tanggal kesepakatan.

Dari tahapan proses tersebut, dan hasil wawancara penulis dengan Bapak Bachtiar diperoleh keterangan bahwa musyawarah yang dilakukan terkait dengan rancangan Perdes tersebut hanya formalitas saja, dikarenakan mayoritas undangan yang hadir dalam musyawarah tersebut menyetujui hasil rancangan yang diajukan oleh pemerintah desa. Terkait bagaimana peran masyarakat dalam musyawarah tersebut, dalam hal ini masyarakat tidak dilibatkan dikarenakan setiap dusun sudah diwakilkan oleh tokoh-tokoh adat, tokoh masyarakat, tokoh agama, dan tokoh pemuda yang dianggap perwakilan dan dipercaya oleh masyarakat desa setiap dusun.

\footnotetext{
${ }^{14}$ Menurut Bapak Bachtiar saat diwawancarai hari Minggu 22 Maret 2015, Pukul 08.00 WIB.
} 
Kurangnya partisipasi masyarakat didalam musyawarah terkait rancangan Perdes menurut Bapak Bachtiar selaku ketua BPD bahwa selama ini masyarakat percaya sepenuhnya dengan rancangan Perdes yang dibuat oleh pemerintah desa, dan sudah ada tokoh-tokoh di dalam setiap dusun yang dianggap wakil dari masyarakat dusun yang dipercaya mampu menyampaikan aspirasi masyarakat desa.

Hal lain yang menjadi penyebab kurangnya minat masyarakat yaitu pola pikir masyarakat desa yang selalu matrialistis, yang dimaksud matrialistis dalam hal ini adalah pemahaman masyarakat bahwa mereka mau hadir dalam acara musyawarah apabila ada uang. Jika tidak ada uangnya mereka enggan untuk berpartisipasi dalam musyawarah terkait rancangan Perdes dan hal-hal yang terkait dengan penyelenggaraan pemerintahan desa.

Selanjutnya, Bapak Bachtiar menjelaskan yang menjadi kendala dalam penyusunan Perdes yaitu:

1) Belum pernah ada pelatihan terkait penyusunan Perdes;

Selama ini penyusunan Rancangan Perdes di desa bojong, dibuat oleh Kades dikarenakan Kades yaitu Bapak Hasan Waka dianggap sebagai Kades yang mampu dalam segala bidang dan pengetahuannya terkait permasalahan hukum, dan menyusun draft rancangan Perdes tersebut.

2) Tugas pokok dan fungsi BPD sebenarnya tidak mengetahui bagaimana yang seharusnya diperintahkan oleh UU;

Dari hasil wawancara, penulis berpendapat bahwa selama ini BPD tidak mengetahui bagaimana tugas pokok dan fungsi BPD sebagaimana diatur dalam peraturan perundang-undangan.

Selama ini BPD hanya mengetahui tugasnya hanya sebagai lembaga permusyawaratan desa yang berperan dalam menyediakan fasilitas dan mengundang tokoh-tokoh masyarakat di desa untuk melakukan musyawarah desa terkait dengan rancangan Perdes, dan setelah terjadi kesepakatan dalam musyawarah desa disampaikan oleh pimpinan BPD kepada Kades untuk ditetapkan menjadi Perdes.

3) Rendahnya tingkat pendidikan masyarakat desa.

Rendahnya tingkat pendidikan masyarakat di desa Bojong menurut Bapak Bachtiar dikarenakan mayoritas masyarakat desa Bojong tidak ada yang menempuh pendidikan. Hal tersebut dapat terlihat pada tabel dibawah ini:

Tingkat pendidikan masyarakat desa Bojong adalah sebagai berikut:

Tabel : Tingkat Pendidikan

\begin{tabular}{|l|l|l|l|l|}
\hline Pra sekolah & SD & SMP & SLTA & Sarjana \\
\hline 1683 & 1262 & 665 & 450 & 55 \\
\hline
\end{tabular}


Dari keterangan tabel diatas, dapat tergambar jelas bahwa masyarakat desa Bojong tingkat pendidikannya hanya sebatas Sekolah Dasar, (SD) dan Lulusan Sarjana di desa Bojong sendiri sangat minim. Pengetahuan masyarakat terkait penyusunan Perdes, tidak banyak yang mampu menyusun Perdes, dan partisipasi masyarakat dalam musyawarah desa sangat minim.

Hal tersebut menurut Bapak Bachtiar, yang menjadi kendala kurang optimal nya peran BPD dalam mewujudkan pembentukan Perdes yang partisipatif di desa Bojong. Selanjutnya, hal yang menarik menjadi perhatian penulis pada saat wawancara dengan Bapak Bachtiar yaitu masalah arsiparsip Perdes yang ada pada saat masa beliau menjabat menjadi ketua BPD.

Bapak Bachtiar beralasan, tidak mengetahui keberadaan arsip-arsip tersebut dengan alasan karena sudah bukan tanggung jawab beliau lagi untuk menyimpan salinan Perdes yang ada selama menjabat dan sudah tidak mengetahui arsip tersebut disimpan dimana.

Menurut Bapak Habib Asnawawi, S.Pd.I selaku Ketua BPD ${ }^{15}$ di desa Bojong Periode 2013-2018 menjelaskan bahwa proses pembentukan Perdes di desa Bojong yaitu:

1) Rancangan Perdes diprakarsai oleh Pemerintah Desa;

2) BPD mengusulkan rancangan Perdes kepada pemerintah desa;

3) Rancangan Perdes dikonsultasikan kepada masyarakat desa untuk mendapat masukan dengan mengadakan musyawarah desa yang diadakan di balai desa. Dalam musyawarah desa dihadiri oleh tokoh-tokoh yang ada di desa bojong, Kades, Sekdes, dan BPD;

4) Rancangan Perdes sebagaimana yang dimaksud ditetapkan oleh Kades setelah disepakati dan dibahas bersama oleh BPD;

5) Rancangan Perdes yang telah disepakati bersama, disampaikan oleh pimpinan BPD kepada Kades untuk ditetapkan menjadi Perdes terhitung sejak tanggal kesepakatan;

6) Rancangan Perdes ditetapkan dan ditandatangani oleh Kades dan ketua BPD.

Tahapan pembentukan Perdes tersebut, diperoleh dari hasil wawancara dengan Ketua BPD dan dijelaskan lebih rinci bahwa dalam proses pembentukan Perdes di desa Bojong peran BPD adalah sebagai lembaga permusyawaratan desa yang menyediakan fasilitas pemerintah desa untuk melakukan musyawarah desa terkait dengan rancangan Perdes Bojong.

Minimnya pengetahuan mengenai tugas dan fungsi BPD dalam pembentukan Perdes selama ini, hanya sebatas melanjutkan dan melihat peran BPD periode sebelumnya. Berikut ini merupakan struktur BPD desa Bojong Kecamatan Sekampung Udik Lampung Timur periode 2013-2018.

${ }^{15}$ Menurut Bapak Habib Asnawawi saat diwawancarai pada hari Minggu 22 Maret 2015, Pukul 11.00 WIB. 


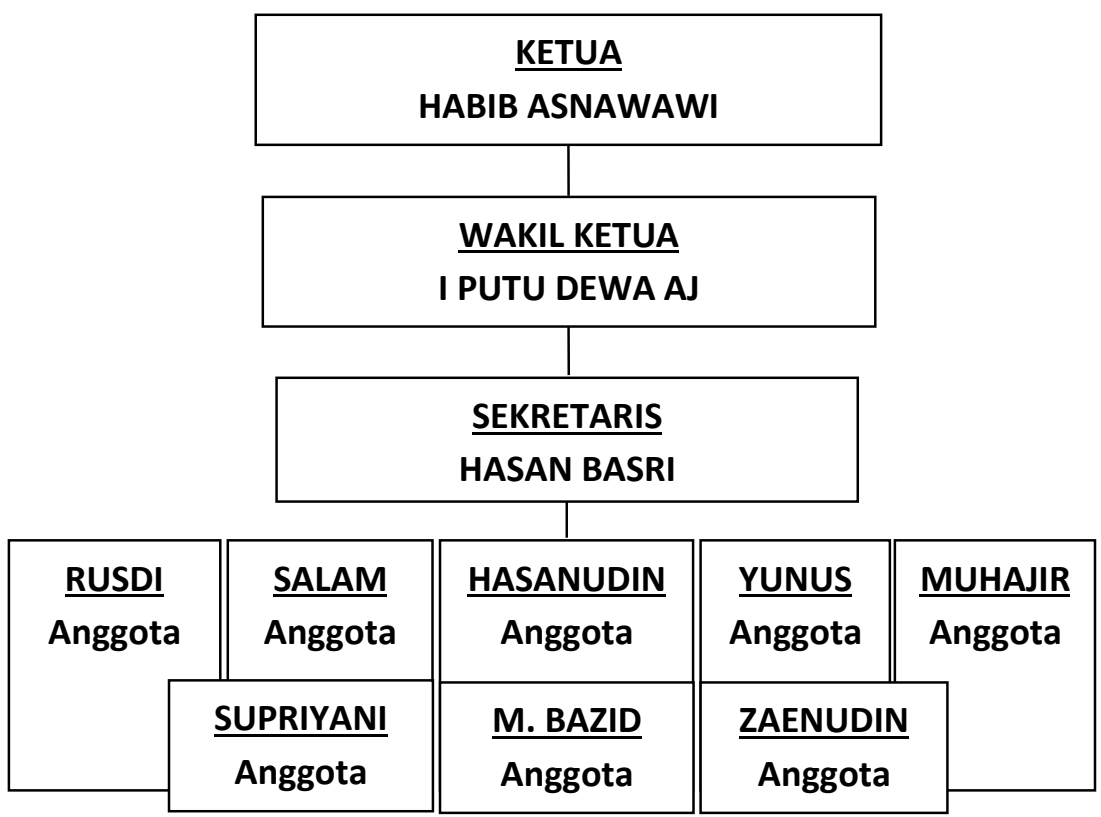

Berdasarkan hasil gambaran umum diatas, terkait struktur BPD desa Bojong Kecamatan Sekampung Udik Lampung Timur, menurut penulis berdasarkan hasil wawancara dengan ketua BPD Habib Asnawawi, terkait menjadi anggota BPD tersebut dipilih berdasarkan keterwakilan wilayah pada masing-masing dusun.

Mekanisme pemilihan menjadi anggota BPD tersebut dilaksanakan secara perwakilan yang pengisiannya dilakukan secara partisipatif. Partisipatif yang dimaksud, setiap dusun mengadakan musyawarah dengan memilih wakil dari penduduk desa yang bersedia menjadi anggota BPD berdasarkan keterwakilan wilayah.

Selanjutnya, setelah terpilih menjadi anggota BPD berdasarkan keterwakilan wilayah, tahapan selanjutnya dilakukan musyawarah sesama anggota BPD terpilih untuk menentukan siapa yang akan menjadi Ketua BPD. Mekanisme pemilihan Ketua BPD, dilakukan dengan cara voting suara terbanyak oleh anggota BPD terpilih dengan menunjuk siapa yang dianggap berhak memimpin BPD Desa Bojong.

Hal yang menarik menurut penulis, setelah dilakukan wawancara dengan Ketua BPD desa Bojong Bapak Habib Asnawawi beliau mengatakan dalam proses menentukan pemimpin Ketua BPD dilakukan dengan sistem tunjuk suara terbanyak dan sebatas sejauh mana calon pemimpin tersebut dekat dengan Kades.

Berdasarkan hal tersebut penulis berkesimpulan bahwa, Peran BPD sebagai lembaga permusyawaratan desa yang dipilih secara partisipatif, tidak 
dapat menjalankan peran dan fungsinya dikarenakan proses pemilihan menjadi Ketua BPD hanya sebatas sejauh mana calon Ketua BPD mempunyai kedekatan dengan Kades. Minimnya pengetahuan BPD yang seharusnya memprakarsai pembentukan Perdes, yang terjadi selama ini adalah Perdes tersebut diprakarsai dan dirancang oleh Kades. Persyaratan calon anggota BPD adalah:

1) Bertakwa kepada Tuhan Yang Maha Esa;

2) Memegang teguh dan mengamalkan Pancasila, melaksanakan UUD 1945, serta mempertahankan dan memelihara keutuhan NKRI dan Bhineka Tunggal Ika;

3) Berusia paling rendah 20 (dua puluh) tahun atau sudah pernah menikah;

4) Berpendidikan paling rendah tamat sekolah menengah pertama atau sederajat. Dalam hal ini penulis berkesimpulan, bahwa peran BPD dalam mewujudkan pembentukan Perdes belum optimal, dikarenakan minimnya tingkat pendidikan anggota BPD tersebut, sehingga peran BPD yang seharusnya memprakarsai dan merancang Perdes belum sepenuhnya menjalankan tugas dan fungsinya sebagaimana mestinya dikarenakan minimnya tingkat pendidikan masyarakat desa Bojong tersebut.

Dari hasil gambaran diatas terkait struktur BPD, penulis menyimpulkan bahwa struktur BPD yang ada di desa Bojong, jumlah anggotanya melebihi batas maksimal jumlah anggota BPD yang ditetapkan di dalam UU Nomor 6 Tahun 2014 tentang Desa, Pasal 58 yang berbunyi: “ Jumlah anggota BPD ditetapkan dengan jumlah gasal, paling sedikit 5 (lima) orang dan paling banyak (sembilan) orang, dengan memperhatikan wilayah, perempuan, penduduk, dan kemampuan keuangan desa.

Terkait dengan jumlah anggota BPD, yang melebihi batas maksimal jumlah anggota seperti yang diatur dalam UU Nomor 6 Tahun 2014 tentang Desa, hasil wawancara penulis dengan Ketua BPD Bapak Habib Asnawawi, beliau beralaskan tidak mengetahui terkait jumlah anggota BPD yang diatur di dalam UU nomor 6 Tahun 2014. Dikarenakan, selama ini jumlah anggota BPD tersebut berdasarkan keterwakilan wilayah pada masing-masing dusun dan kemampuan keuangan desa.

Selanjutnya, ada beberapa hal yang menjadi kendala dialami oleh BPD dalam pembentukan Perdes yaitu:

1) Belum pernah diadakan penyuluhan hukum baik dari pemerintah Kabupaten Lampung Timur maupun pemerintah desa terkait dengan peran BPD dalam pembentukan Perdes;

2) Kurangnya sarana dan prasarana desa sebagai alat yang digunakan untuk membentuk rancangan Perdes;

3) Minimnya lulusan Sarjana Hukum di desa Bojong;

4) Kurang aktifnya partisipasi masyarakat desa dalam menyatakan pendapat dan memberi masukan dalam rancangan Perdes; 
5) Landasan hukum yang digunakan BPD dalam penyusunan rancangan Perdes tidak mengetahui, dikarenakan selama ini hanya mengikuti format-format Perdes terdahulu.

6) Kurang mengetahui tugas pokok dan fungsi BPD dalam peraturan perundang-undangan selain sebagai lembaga yang berperan dalam pembentukan Perdes.

7) Selama ini tidak ada penyuluhan hukum terkait dengan pembentukan Perdes.

Berdasarkan hasil wawancara dengan Ketua BPD tersebut, penulis dapat menyimpulkan bahwa peran BPD Bojong dalam mewujudkan pembentukan Perdes yang partisipatif sudah berjalan, namun belum secara penuh dilakukan secara partisipatif dikarenakan peran BPD yang seharusnya memprakrasai dan menyusun rancangan Perdes yang terjadi adalah Perdes tersebut diprakarsai dan dirancang oleh Kades.

BPD yang seharusnya, sebagai lembaga permusyawaratan yang memprakarsai dan merancang Perdes, namun kenyataannya BPD hanya sebagai lembaga permusyawaratan desa yang hanya berperan menyediakan fasilitas dan mengadakan musyawarah desa terkait rancangan Perdes yang disusun oleh pemerintah desa dalam hal ini Kades. Kurangnya pengetahuan BPD mengenai tugas dan fungsinya dalam peraturan perundang-undangan menyebabkan peran BPD selama ini berjalan kurang optimal dan tidak sepenuhnya BPD mewakili mayarakat desa.

Selanjutnya, hal lain yang menjadi kendala peran BPD belum berjalan secara optimal, adalah peran tokoh-tokoh masyarakat yang dipercayai masyarakat desa masing-masing dusun menyampaikan aspirasi dan masukan terkait rancangan Perdes, belum sepenuhnya mewakili hal-hal yang menjadi keinginan dan masukan dari masyarakat desa dalam pembentukan rancangan Perdes.

Kepercayaan masyarakat desa Bojong, terhadap para tokoh-tokoh masyarakat yang dianggap mampu menampung dan menyampaikan aspirasi masyarakat dalam musyawarah desa terkait pembentukan Perdes beralasan, dikarenakan tokoh-tokoh tersebut mempunyai pengaruh besar di desa Bojong. Pengaruh besar yang dimaksud, tokoh-tokoh masyarakat desa tersebut turut aktif berpartisipasi baik formil maupun materiil dalam proses penyelenggaraan pemerintahan desa.

\section{c. Hasil wawancara dengan Masyarakat Desa Bojong}

Menurut Mahmud, ${ }^{16}$ selaku masyarakat desa yang sebelumnya pernah menjadi anggota BPD periode 2009-2013 peran masyarakat dalam musyawarah desa terkait dengan peran BPD dalam membentuk Perdes yang

\footnotetext{
${ }^{16}$ Menurut Bapak Mahmud, saat diwawancarai hari Sabtu 28 Maret 2015, Pukul 15.00 WIB.
} 
partisipatif dilapangan tidak dapat terlaksana, dikarenakan masyarakat desa tingkat partisipasi dalam musyawarah desa tidak terlalu menjadi prioritas.

Hal tersebut dikarenakan, mereka beranggapan bahwa acara tersebut tidak memberikan pengaruh besar terhadap kehidupan sehari-hari mereka dan tidak punya nilai lebih jika yang dapat diperoleh jika ikut dalam musyawarah desa. Nilai lebih yang dimaksud adalah nilai uang yang diperoleh jika ikut musyawarah desa.

Rendahnya pola pikir masyarakat desa yang dimana segala sesuatu hal dikaitkan dengan keuntungan/uang menyebabkan rendahnya partisipasi masyarakat baik dalam musyawarah desa terkait masukan dan partisipasinya dalam pembentukan Perdes ataupun hal-hal lainnya yang terkait dengan penyelenggaran pemerintahan desa. Hal-hal lain, yang menyebabkan kurangnya partisipasi masyarakat desa Bojong yaitu minimnya tingkat pendidikan lulusan sarjana. Masyarakat desa Bojong, mayoritas tidak menempuh jalur pendidikan dan paling banyak hanya sebatas lulusan Sekolah Dasar (SD).

Menurut hasil wawancara penulis dengan Bapak Holidan ${ }^{17}$, selaku masyarakat desa Bojong terkait dengan peran BPD dalam mewujudkan pembentukan Perdes yang partisipatif, beliau berpendapat tidak mengetahui secara detail mengenai tugas dan fungsi BPD tersebut. Bapak Holidan, beliau hanya mengetahui bahwa BPD merupakan lembaga permusyawaratan desa yang bekerjasama dengan Kades membuat Perdes.

Selanjutnya, penulis menanyakan terkait dengan peran masyarakat desa Bojong dalam pembentukan Perdes yang partisipatif, beliau menyatakan bahwa masyarakat desa Bojong selama ini, tidak ikut berpartisipasi, dikarenakan sudah diwakilkan oleh tokoh-tokoh masyarakat yang ada di setiap dusun yang merupakan wakil yang dianggap mampu menyalurkan aspirasi warga desa yang ada pada setiap masing-masing dusun.

Rendahnya partisipasi masyarakat, dalam pembentukan Perdes beliau beralasan, bahwa selama ini masyarakat sudah percaya terhadap Perdes yang dirancang oleh Kades telah cukup baik selama ini, dan hal lain yang menjadi alasan utama rendahnya partisipasi masyarakat desa Bojong, dikarenakan masih banyak pekerjaan rumah yang perlu dikerjakan masyarakat desa untuk mencukupi kebutuhan perekonomian keluarga, dibandingkan dengan ikut berpartisipasi dalam pembuatan Perdes. Masyarakat desa Bojong, tidak mengetahui betapa pentingnya keterlibatan masyarakat desa dalam pembentukan Perdes di desa Bojong.

\footnotetext{
${ }^{17}$ Menurut Bapak Holidan saat diwawancarai, hari Sabtu 28 Maret 2015, Pukul 19.00 WIB.
} 
Selanjutnya, penulis melakukan wawancara dengan salah satu masyarakat desa Bojong bernama Ibu Kasih. Menurut Ibu Kasih, ${ }^{18}$ peran BPD di desa Bojong adalah sebagai lembaga permusyawaratan desa untuk membentuk Perdes bersama Kades. Terkait dengan pentingnya partisipasi masyarakat, dalam pembentukan Perdes menurut Ibu Kasih, masyarakat di desa Bojong kurang terlalu peduli akan pembentukan Perdes selama ini, dikarenakan masyarakat desa lebih memprioritaskan tentang kehidupan perekonomian keluarganya dibandingkan dengan ikut musyawarah desa dalam pembentukan Perdes.

Kurangnya pengetahuan masyarakat desa Bojong, akan pentingnya peran dan aspirasi masyarakat desa dalam mewujudkan Perdes yang partisipatif, dikarenakan keterwakilan tokoh-tokoh yang dianggap masyarakat dapat menyampaikan aspirasi dan masukan masyarakat desa, pada pelaksanaannya tidak sepenuhnya optimal menyampaikan masukan dan aspirasi masyarakat desa masing-masing dusun.

Dari keterangan yang telah dijelaskan diatas, hasil wawancara dengan pihak Eksekutif desa, Legislatif desa, dan Masyarakat desa, dalam hasil penelitian yang dilakukan penulis di desa Bojong, terkait dengan Peran BPD dalam pembentukan Perdes yang Partisipatif di Kabupaten Lampung Timur di desa Bojong, penulis dapat menyimpulkan bahwa Peran BPD dalam mewujudkan pembentukan Perdes yang partisipatif belum secara optimal dilakukan, dikarenakan beberapa alasan yaitu :

1) Perdes di desa Bojong selama ini diprakarsai dan dirancang oleh Kades.

2) Minimnya pengetahuan ketua BPD terkait tugas dan fungsi BPD dalam peraturan perundang-undangan;

3) Minimnya pengetahuan BPD terkait proses dan mekanisme pembentukan Perdes yang partisipatif. Dikarenakan selama ini belum pernah ada sosialisasi dari Pemda Kabupaten Lampung Timur terkait pembentukan Perdes

4) BPD kurang bersinergi dengan masyarakat dalam proses pembentukan Perdes untuk mendapatkan masukan dan aspirasi masyarakat terhadap rancangan Perdes tersebut. Dikarenakan selama ini, beralaskan sudah diwakilkan oleh tokoh-tokoh masyarakat desa yang ada di setiap dusun yang dianggap mampu menyampaikan aspirasi masyarakat desa dalam musyawarah desa;dan,

5) Sehingga, apa yang menjadi aspirasi dan masukan masyarakat desa dalam musyawarah desa pembentukan rancangan Perdes dengan diwakilkan oleh tokoh-tokoh masyarakat tersebut belum secara optimal menjawab hal yang menjadi keinginan masyarakat desa .

\footnotetext{
${ }^{18}$ Menurut Ibu Kasih pada saat diwawancarai, hari Minggu 29 Maret 2015, Pukul 10.00 WIB.
} 
Seharusnya, BPD merupakan lembaga yang diberikan wewenang oleh UU untuk melaksanakan fungsi pemerintahan berdasarkan keterwakilan wilayah yang ditetapkan secara demokratis.

Dasar pembenar BPD diberikan wewenang tersebut dikarenakan di dalam menyelenggarakan pemerintahan desa BPD selaku lembaga yang ditetapkan secara demokratis memiliki peran untuk mengawasi dan meminta keterangan tentang penyelenggaraan pemerintahan desa kepada pemerintah desa, menyatakan pendapat atas penyelenggara pemerintahan desa, pelaksanaan pembangunan desa, pembinaan kemasyarakatan desa, dan pemberdayaan masyarakat desa.

Seharusnya, BPD di desa Bojong saat ini menjalankan peran nya sebagai lembaga yang partisipatif seperti yang telah diatur di Pasal 55 UU Nomor 6 Tahun 2014 tentang Desa, mengatur bahwa BPD mempunyai fungsi untuk membahas dan menyepakati rancangan Perdes bersama Kades, menampung dan menyalurkan aspirasi masyarakat, dan melakukan pengawasan kinerja Kades. Selanjutnya, didalam konsideran dijelaskan bahwa BPD merupakan badan permusyawaratan desa yang turut membahas dan menyepakati berbagai kebijakan dalam penyelenggaraan pemerintahan desa. Dalam upaya meningkatkan kinerja kelembagaan di tingkat desa, memperkuat kebersamaan, serta meningkatkan partisipasi dan pemberdayaan masyarakat, pemerintah desa dan/atau BPD memfasilitasi penyelenggaraan musyawarah desa. ${ }^{19}$

Fakta dilapangan, menunjukan bahwa BPD di desa Bojong belum secara optimal menjalankan perannya sebagai lembaga dalam mewujudkan pembentukan Perdes yang partisipatif, sebagaimana yang diatur dalam peraturan perundang-undang, dikarenakan dalam musyawarah desa keterlibatan tokoh-tokoh yang dianggap mewakili suara dan aspirasi masyarakat desa belum secara penuh mewakili hal-hal yang menjadi keinginan dan masukan dari masyarakat desa Bojong.

Hal tersebut dirasakan belum berjalan secara optimal, dikarenakan pada Pasal 68 UU Nomor 6 Tahun 2014 tentang desa, dijelaskan bahwa masyarakat desa berhak untuk menyampaikan aspirasi, saran, dan pendapat lisan atau tertulis secara bertanggung jawab tentang kegiatan penyelenggaraan pemerintahan desa, pelaksanaan pembangunan desa, pembinaan kemasyarakatan desa, dan pemberdayaan masyarakat desa.

Selanjutnya, masih terkait partisipasi masyarakat desa, pada Pasal 96 UU Nomor 12 Tahun 2011 tentang Pembentukan Peraturan Perundang-

${ }^{19}$ Musyawarah desa adalah musyawarah antara Badan Permusyawaratan Desa, Pemerintah Desa, dan unsur masyarakat yang diselenggarakan oleh Badan Permusyawaratan Desa untuk menyepakati hal-hal yang bersifat strategis. 
Undangan bahwa masyarakat berhak memberikan masukan secara lisan dan/atau tertulis dalam pembentukan peraturan perundang-undangan.

\section{Penutup}

\section{Simpulan}

Berdasarkan penjelasan tersebut, penulis berkesimpulan peran BPD Bojong dalam mewujudkan pembentukan Perdes yang partisipatif sudah berjalan secara partisipatif, akan tetapi belum secara optimal, dikarenakan peran dari tokoh-tokoh masyarakat yang mewakili masyarakat desa dalam musyawarah pembentukan rancangan Perdes, belum sepenuhnya menjawab hal-hal yang menjadi keinginan dan masukan masyarakat desa terkait dengan rancangan Perdes yang akan disusun oleh BPD.

\section{Saran}

Masukan secara lisan dan/atau tertulis sebagaimana dimaksud dapat dilakukan melalui rapat dengar pendapat, kunjungan kerja, sosialisasi, seminar, lokakarya, dan/atau diskusi. Untuk memudahkan masyarakat memberikan masukan secara lisan dan/atau tertulis, setiap rancangan peraturan perundang-undangan harus dapat diakses dengan mudah oleh masyarakat.

Selanjutnya, hal-hal lain yang menjadi kendala adalah dalam hal memberikan masukan secara lisan dan/atau tertulis yang dapat dilakukan melalui rapat dengar pendapat, kunjungan kerja, sosialisasi, seminar, lokakarya dan/atau diskusi yang terjadi hanya diadakan musyawarah desa terkait rancangan Perdes dan setelah ditetapkan menjadi Perdes tidak ada sosialisasi dari pemerintah desa Bojong kepada masyarakat desa terkait hasil rancangan Perdes yang telah ditetapkan menjadi Perdes.

\section{Daftar Pustaka}

\section{A. Buku}

Sasongko, Wahyu. (2013). Sejarah Tata Hukum Indonesia. Bandar Lampung: PKKPU FH Unila.

Muhammad, Abdulkadir. (2004). Hukum dan Penelitian Hukum. Bandung: PT Citra Aditnya Bhakti.

\section{B. Peraturan Perundang-Undangan}

Undang-Undang Nomor 12 Tahun 2011 tentang Pembentukan Peraturan Perundang-Undangan

Undang-Undang Nomor 6 Tahun 2014 tentang Desa 